\title{
Real time echo-guided endolaser for thermal ablation without perivenous tumescence
}

\author{
Endolaser ecoguiado em tempo real para termoablação sem intumescência perivenosa
}

Ricardo José Gaspar ${ }^{1,2,3}$, André Nóbrega Castro ${ }^{4}$, Manuel de Jesus Simões ${ }^{5}$, Hélio Plapler ${ }^{6}$

\begin{abstract}
Background: There is no consensus in the medical literature on the ideal procedure for endovenous laser application. Objective: To assess the safety and efficacy of real time echo-guided endovenous laser for thermal ablation of great saphenous vein (GSV) incompetence, without perivenous tumescence. Methods: Thirty-four limbs of patients with CEAP clinical scores of 2 to 6 and bilateral incompetence of the saphenofemoral junction (SFJ) and GSV, confirmed by Echo-Doppler, underwent endovenous laser therapy and were followed for 1 year. Laser ablation was performed using a $600 \mu$ bare optical fiber introduced endovenously close to the malleolus along the full extent of the GSV in an anterograde direction, using a standardized echo-Doppler-guided AND? 15 watt continuous mode $980 \mathrm{~nm}$ diode laser with real-time monitoring of thermal ablation of the whole target vein. Adverse effects and complications were recorded. Results: Hyperesthesia, cellulitis, and fibrous cord, all transitory, developed in $2.9 \%$ of the 34 limbs treated; 8.8\% developed hypoesthesia in the perimalleolar region, which was transitory and had no clinical consequences; there were no cases of deep venous thrombosis. Immediate occlusion was achieved in 100\% of the 34 saphenous veins that underwent photocoagulation, although one exhibited recanalization without reflux at 1-month follow-up. After 6 months and 1 year, occlusion was 100\% according to echo-Doppler findings. Conclusions: Real-time echo-guided $980 \mathrm{~nm}$ endovenous laser ablation without perivenous tumescence provided controlled thermal ablation with safe, effective, immediate and medium-term GSV occlusion and can therefore be recommended as a method for the treatment of chronic venous disease.
\end{abstract}

Keywords: varicose veins; venous insufficiency; saphenous vein; laser therapy.

\begin{abstract}
Resumo
Contexto: Não há consenso na literatura médica sobre qual técnica é a ideal para aplicação do endolaser. Objetivos: Avaliar a segurança e a eficácia do endolaser ecoguiado em tempo real para termoablação da veia safena magna (VSM) insuficiente, sem intumescência perivenosa. Métodos: Trinta e quatro membros de pacientes em estágio clínico CEAP 2 a 6, com incompetência bilateral da junção safeno-femoral e da VSM, confirmada por eco-Doppler, foram submetidos à terapia por endolaser e acompanhados por um período de um ano. A aplicação foi feita por meio de fibra condutora de $600 \mu$, introduzida por via endovenosa, ao nível da região perimaleolar por toda VSM, sentido anterógrado, utilizando laser diodo com 15 w de potência e 980 nm de comprimento de onda, no modo contínuo, guiado por eco-Doppler, e forma padronizada para monitoração em tempo real da termoablação de toda a veia-alvo. Foram anotados os efeitos adversos e as complicações. Resultados: Dos 34 membros tratados, 2,9\% apresentaram hiperestesia, celulite e cordão fibroso, todos transitórios; em 8,8\%, constatou-se hipoestesia perimaleolar, transitória e sem repercussão clínica; não houve relato de trombose venosa profunda. Das 34 safenas fotocoaguladas, houve 100\% de oclusão imediata, uma recanalização sem refluxo no controle de um mês e 100\% de oclusão após seis meses e um ano, mostrado pelo eco-Doppler. Conclusões: Ablação utilizando endolaser $980 \mathrm{~nm}$, ecoguiado em tempo real, sem intumescência perivenosa, promoveu fotocoagulação suficientemente controlada, com oclusão imediata e em médio prazo da VSM, de forma segura e eficaz, e configura-se como método terapêutico recomendável para o tratamento da doença venosa crônica.
\end{abstract}

Palavras-chave: varizes; insuficiência venosa; veia safena/cirurgia; terapia a laser.

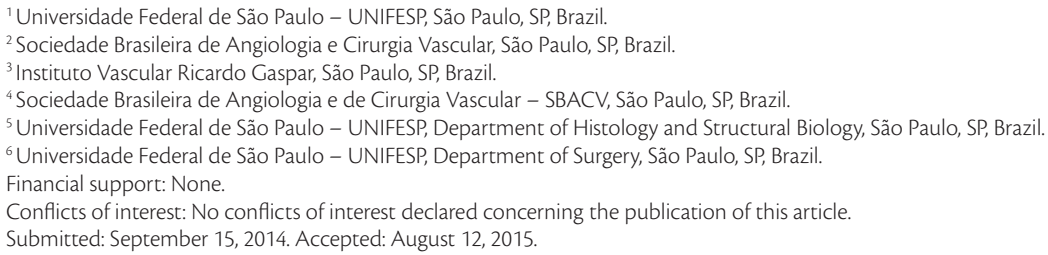




\section{INTRODUCTION}

There is no consensus in the medical literature on the ideal procedure for endovenous laser application and there are no descriptions of a standard method capable of managing all physical and biological variations using different devices and techniques.

Studies have been conducted to analyze thermal damage caused by endoluminal lasers of different wavelengths and have shown that the main component responsible for vein wall damage is blood vaporization. ${ }^{1-4}$ Additionally, a small number of histological studies have observed the changes to the great saphenous vein (GSV) caused by the action of heat. ${ }^{5}$ Some preliminary findings from investigations of limbs that have undergone endovenous laser treatment appear to indicate that endovenous laser irradiation is always followed by thrombosis. ${ }^{2,3,6,7}$ Changes to the vein wall caused by the heat generated by the laser have been described as shrinking by myoglobin contraction, ${ }^{5,89}$ collagen retraction, ${ }^{6,10-15}$ and thrombosis and fibrosis, ${ }^{2,7,15}$ and results are apparently fluence dependent. ${ }^{14}$ Other factors that also appear to influence the practical outcomes of the selective thermal action of endovenous lasers include vein wall diameter and thickness and optical fiber conditions and pull-back speed, venous tone, immediate spasm, blood volume and blood vaporization, ${ }^{12,14}$ as well as the presence of reflux points caused by incompetent tributary and perforating veins. ${ }^{3}$

In view of the above, this study investigated whether use of a real-time echo-guided endovenous laser thermal ablation method would increase safety and efficacy and reduce adverse effects and recanalization prevalence. Parameters were recorded over a 1-year follow-up period, during which patients were evaluated at regular intervals.

\section{MATERIALS AND METHODS}

This study was performed under supervision by the Graduate Course in Surgery and Experimentation at the Universidade Federal de São Paulo - Escola Paulista de Medicina (UNIFESP-EPM) and was approved by the Research Ethics Committees at UNIFESP-EPM and the Santa Catarina, Bandeirantes and Igesp Hospitals, where the procedures were performed. Patients were enrolled on the study after signing informed consent forms. All surgical procedures were performed by the same surgery team. Patients with suspected lower limb chronic venous disease underwent clinical assessment. Those with confirmed diagnoses of venous disease and indications for surgical treatment were selected to receive endovenous laser therapy. Inclusion criteria were age greater than 21 years, indications for surgical treatment of primary varices, bilateral GSV and saphenofemoral junction (SFJ) reflux confirmed by color echo-Doppler findings and clinical stage 2 to 6 according to the Clinical Etiology Anatomy Pathophysiology (CEAP) classification, which sets standards for stratification of chronic venous diseases. ${ }^{16}$ Exclusion criteria were valve insufficiency in deep veins or post thrombotic syndrome, mental conditions, severe ongoing infectious diseases, uncontrolled hypertension and severe heart disease. All 17 patients (100\%) underwent bilateral endovenous laser treatment. All incompetent tributary and perforating veins mapped by echo-Doppler were recorded and those topographically related to the GSV were marked with an arrow drawn with a pen specifically designed for writing on skin, containing ink that cannot be removed by antiseptics. After spinal anesthesia, patients were positioned on the operating table in the horizontal dorsal position. An incision was then made at the inguinal fold and the SFJ was dissected, followed by high ligation, crossectomy and ligature of tributary veins. The GSV was catheterized via the malleolus region, where a 600 -micron-wide bare optical fiber, connected to the $980 \mathrm{~nm}$ diode laser (Model Ceralas D15, Biolitec brand, manufacturer Biolitec Biomedical Technology) with $15 \mathrm{~W}$ power density, was inserted using either needle cannula or vein dissection. The equipment used is approved and regulated by the Brazilian National Health Surveillance Agency (Agência Nacional de Vigilância Sanitária [ANVISA], registration number 80162040002). After GSV catheterization via the malleolus region, the laser fiber was introduced in the ascending direction, with real-time visualization using echo-Doppler in $\mathrm{B}$ mode, until it reached the level of the vein ligation in the SJF. Its position was also confirmed by direct observation of the laser light by trans-illumination through the skin near the inguinal incision. Thermal exposure time was determined according to thrombosis parameters on the basis of echo-Doppler findings. After visualization by ultrasound of the fiber tip inside the vein lumen in a longitudinal section, laser light was applied in continuous mode, and blood boiling was confirmed by the presence of steam bubbles (Figure 1). As echo-Doppler showed the complete occlusion by thrombosis of each centimeter of the treated segment (Figure 2), the optical fiber was manually withdrawn caudally in a gradual motion without using any type of mechanical device. After photocoagulation of each $20 \mathrm{~cm}$, laser discharges were interrupted to perform a proximal sweep of a cross-section and reconfirm obliteration by detection of hyperechogenic material, 


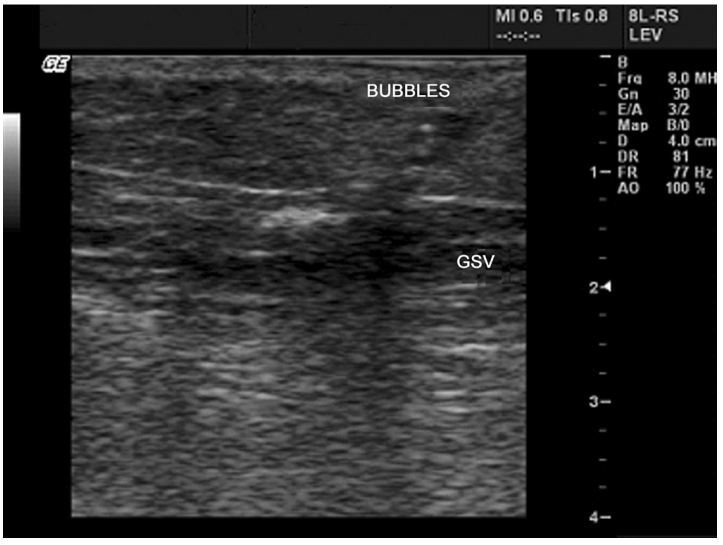

Figure 1. Real-time echo-guided photoablation. Blood vaporizes inside the great saphenous vein (GSV) lumen, with steam bubbles migrating to tributary vein.

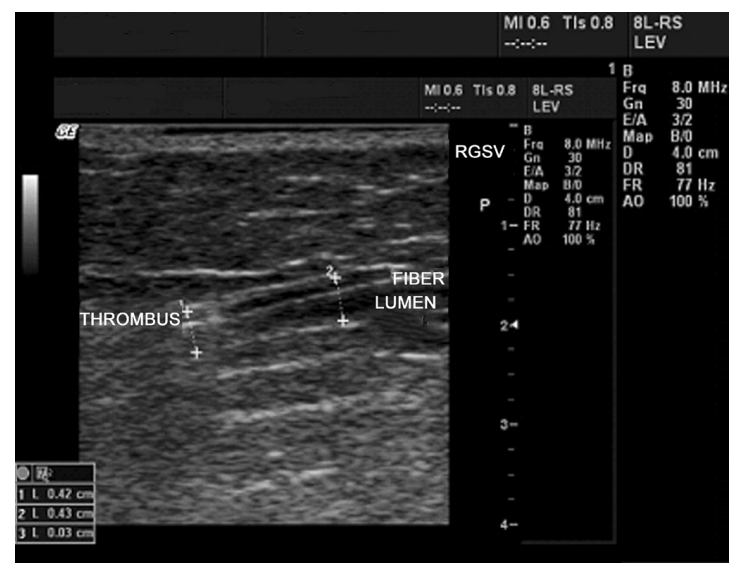

Figure 2. Real-time echo-guided photoablation. Thrombus occludes the target-vein lumen during optical fiber pull-back.

acoustic shadow, and vein incompressibility (Figure 3). If any segments remained patent, the optical fiber was advanced cranially once more for another laser application. The laser power used for each venous segment ranged from $4 \mathrm{~W}$ to $15 \mathrm{~W}$, depending on the lumen diameter (with maximum densities of two times the vessel diameter in the thigh and no more than one and a half times in the leg ${ }^{17}$ and the depth from the skin. Therefore, different energy emissions and optical fiber pull-back speeds were used. Laser pulses were interrupted when a point about five centimeters cranial of the malleolus had been reached. The following additional surgical procedures were performed with patients placed in the Trendelemburg position: phlebectomy and/or ligature of varicose and incompetent perforating-communicating veins via mini-incisions, and closure of the inguinal and perimalleolar incisions using polyamide suture and semi-compressive occlusive dressing with cotton

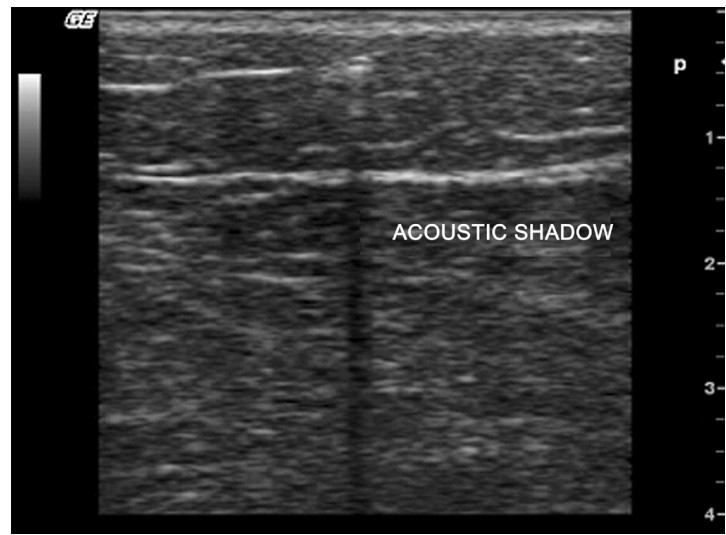

Figure 3. Total occlusion of the great saphenous vein was confirmed in cross-section with hyperechogenic material and acoustic shadow.

stockinettes and crepe bandage for the full length of the lower limbs. All patients were discharged from hospital on the same day, after recovery from anesthesia, and none of them needed to stay in hospital overnight. The following day, all dressings were removed and the patients were instructed to wash the area, rest for 1 hour and then put on medium compression elastic support stockings (20-30 mm Hg), after which they were to begin walking immediately. The patients were then instructed to wear elastic support stockings daily for 15 days and perform their usual daily activities, but avoid exercising for 15 days. A return appointment was set for 7 days later, when possible adverse effects such as infection of the incision sites, cellulitis, erysipelas, thrombophlebitis, fibrous cord, hyperchromic spots and paraesthesia were recorded and treated.Post-operative control echo-Doppler examinations were conducted after 1, 6 and 12 months and included assessment of the deep venous system to exclude the possibility of venous thrombosis. Remaining tributary veins in the SFJ were sought, and presence or absence of reflux was confirmed using color or spectral mode. Cross-sectional B mode echo-Doppler scanning was used to map the whole GSV to evaluate complete occlusion, which was confirmed when the vein was completely filled with hypoechogenic content that could not be compressed by the transducer and also when no flow was detected in the venous lumen using color mode. When a patent segment was detected, reflux was assessed and mapped to check whether surgical treatment was indicated.

\section{RESULTS}

Table 1 lists the anatomical features of the saphenous veins treated. All 34 of the saphenous veins that underwent endovenous laser therapy were 
Table 1. Diameter and length variability of the 34 saphenous veins treated.

\begin{tabular}{lc}
\hline & Variation \\
\hline Diameter in the SFJ $(\mathrm{mm})$ & $4.1-12$ \\
Diameter in the knee $(\mathrm{mm})$ & $2.3-11$ \\
Diameter in the leg $(\mathrm{mm})$ & $1.7-5.8$ \\
Length in the thigh $(\mathrm{cm})$ & $29-40$ \\
Length in the leg $(\mathrm{cm})$ & $26-39$ \\
\hline
\end{tabular}

Table 2. Variability of technical parameters for laser application in the 34 saphenous veins treated.

\begin{tabular}{lc}
\hline & Variation \\
\hline Exposure time in the thigh $(\mathrm{s})$ & $233-932$ \\
Exposure time in the leg $(\mathrm{s})$ & $118-736$ \\
Energy in the thigh $(\mathrm{J})$ & $1,926-1,188$ \\
Energy in the leg $(\mathrm{J})$ & $1,014-5,510$ \\
Energy per linear centimeter in the thigh $(\mathrm{J} / \mathrm{cm})$ & $52-290$ \\
Energy per linear centimeter in the leg $(\mathrm{J} / \mathrm{cm})$ & $31-163$ \\
Power density in the thigh $(\mathrm{J} / \mathrm{s})$ & $7.67-13.35$ \\
Power density in the leg $(\mathrm{J} / \mathrm{s})$ & $5.40-11.03$ \\
Optical fiber pull-back speed in the thigh & $0.42-1.54$ \\
(mm/s) & \\
Optical fiber pull-back speed in the leg $(\mathrm{mm} / \mathrm{s})$ & $0.44-2.14$ \\
\hline
\end{tabular}

Table 3. Distribution of adverse effects by prevalence in 34 limbs.

\begin{tabular}{lcc}
\hline & $\mathbf{n}$ & Percent (\%) \\
\hline Limbs treated & 34 & 100 \\
Hyperpigmentation & 1 & 2.9 \\
Hypoesthesia & 3 & 8.8 \\
Hyperesthesia & 1 & 2.9 \\
Cellulites & 1 & 2.9 \\
Fibrous cord & 1 & 2.9 \\
Deep venous thrombosis & 0 & 0 \\
Infection & 0 & 0 \\
\hline
\end{tabular}

completely occluded after the final intraoperative control scan, according to the echo-Doppler parameters adopted. After surgery and recovery from anesthesia, none of the patients complained of bruising or pain requiring prolonged hospitalization. All patients were therefore discharged from hospital on the same day of the procedure and none needed to stay in hospital overnight. Table 2 shows the range of variation in all of the technical parameters obtained after saphenous vein ablation, separately for thighs and legs. Table 3 lists the rates of adverse effects in the 34 limbs treated. Table 4 shows the rates of recanalization after control by echo-Doppler at 1, 6 and 12 months after the procedure. Recanalization without reflux was observed in a short 6-cm segment of one saphenous vein at 1-month follow-up, but this finding was not
Table 4. Distribution of recanalization in saphenous veins treated, at periodic echo-Doppler follow-ups.

\begin{tabular}{lcc}
\hline \multicolumn{1}{c}{$\begin{array}{c}\text { Control with eco-Doppler } \\
\text { examinations }\end{array}$} & n & Percent (\%) \\
\hline $\begin{array}{l}\text { Treated saphenous veins followed } \\
\text { Recanalized saphenous veins } \\
\text { (after 1 month) }\end{array}$ & 34 & 100 \\
$\begin{array}{l}\text { Recanalized saphenous veins } \\
\text { (after 6 months) }\end{array}$ & 0 & 2.9 \\
$\begin{array}{l}\text { Recanalized saphenous veins } \\
\text { (after 12 months) }\end{array}$ & 0 & 0 \\
\hline
\end{tabular}

observed at subsequent follow-ups.At 1-year follow up, no cases of recurrent or persistent varicose veins were observed.

\section{DISCUSSION}

Developments in biotechnology engineering have brought substantial advances in the medical field, with the emergence of new surgical techniques that may be alternatives for or even replace the old ones permanently. Endovascular techniques are capable of offering patients minimally invasive interventions, as is also the case with video surgery, thereby reducing the risks of such procedures. ${ }^{18}$ Therefore, based on evidence from investigations conducted by Boné Salat ${ }^{19}$ and supported by more recent studies, ${ }^{20-22}$ endovenous laser ablation has evolved into a safe and effective alternative for treatment of incompetent GSVs, when compared to conventional surgery (radical phlebectomy). Its major advantage is much faster and more comfortable patient recovery, with an early return to work activities. ${ }^{23,24}$ Most papers analyzing endovenous laser treatment have focused on the GSV and/or on the small saphenous vein (SSV). The indications for the procedure are the same as those for the traditional surgical procedure, i.e. SFJ incompetence with venous reflux, except in cases with a history of deep venous thrombosis. Endovenous lasers have been employed in non-hospital settings using perivenous tumescent local anesthesia along the GSV or the SSV. In these settings, neither crossectomy nor ligature of SFJ tributary veins is performed. ${ }^{6,10,25}$ Most investigators have used 810,940 or $980 \mathrm{~nm}$ diode laser in continuous or pulsed mode and power density between 6 and $15 \mathrm{~W}$. However, some studies have reported use of other types of endovenous laser, such as Nd:Yag and helium/neon, with longer wavelengths $(1,320$ and $1,470 \mathrm{~nm})$ and other choices of chromophores and their respective absorbed energy spectra, which enabled use of much lower energy densities and increased the safety of the procedure 
even further. ${ }^{1,20,26,27}$ Similarly, new radial and tulip fibers have been developed with the aim of providing greater efficacy. ${ }^{27,28}$ It was very important to determine the anatomic variability of saphenous veins, in order to demonstrate the highly significant heterogeneity of the lumens in each segment of the vein and of their lengths in thigh and leg (Table 1). Additionally, these data were critical for establishing the best laser power density for the different segments, together with vein-skin distance detected by echo-Doppler. Vein-skin distances were not recorded, because of their great variability, but they were always higher in the thigh than in the leg, due to the presence of a thicker fat pad, usually measuring $\geq 1 \mathrm{~cm}$ on the thigh. Both diameter and length had a strong influence on the energy released per linear centimeter in thigh and leg segments (Table 2).

There are a very large number of biological variants and physical parameters in the medical literature about endovenous laser application. However, there was previously no method to effectively control the quantity of energy released in the GSV lumen in each segment of the vein. ${ }^{14,18,21}$ Several studies reviewed by Corcos et al., ${ }^{17,29}$ in addition to their own findings, have shown that high energy density used for short periods of time generally leads to an increase in blood and tissue vaporization on the inner wall of the vein. In contrast, low energy density released for long periods of time may decrease vaporization and increase tissue coagulation. There is, therefore, an inverse relationship between the fluence and the area of internal surface that undergoes irradiation, which suggests that different vein diameters require variable exposure times for the same energy density to release the same fluence. In their studies, the variations in energy density were less significant than the variations in optical fiber pull-back speed in vein segments with different diameters and surface areas.

According to Corcos et al., ${ }^{17,29}$ the ideal results of the procedure were obtained in vein segments $<10 \mathrm{~mm}$ diameter. Reduced thermal damage and less penetration was detected in veins $>10 \mathrm{~mm}$ and $<17 \mathrm{~mm}$, although activation of the thrombotic and healing processes was equally satisfactory. The authors therefore inferred that in wider veins a lower degree of wrinkling of the wall should be expected due to less extensive thermal damage in the lumen and a greater massive thrombotic process, with a less satisfactory clinical result. Real-time echo-Doppler-guided endovenous laser application offers several advantages and allows more freedom with regard to several pre-established criteria. In veins with wider segments according to vein-skin distance, power density that was twice the vein diameter was used safely in the thigh; in the leg, power density was calculated as one and a half times the vein diameter; most procedures used 10 to $12 \mathrm{~W}$ in the thigh and 6 to $8 \mathrm{~W}$ in the leg (Table 2). Optical fiber pull-back speed was controlled using echo-Doppler while the thrombotic process to fully occlude the vein was observed, as stated in the method, proving that it is unnecessary to use mechanical devices or equipment for this purpose. In this study, there was evident variation in the linear endovenous energy density (LEED) released and the greatest increase was found in the thigh segments, where applications exceeded the prescribed LEED of $80 \mathrm{~J} / \mathrm{cm}$ (Table 2), ${ }^{17,18,29}$ confirming that this parameter cannot be kept steady. In certain cases, the optical fiber had to be advanced cranially once more for a supplementary reapplication because of partial thrombosis, which was seen using echo-Doppler. Additionally, the safety margin to identify exteriorization of the optical fiber was optimal, and the fiber could be accurately pulled back into the lumen and repositioned. According to one study in the literature, ${ }^{17}$ inability to advance the optical fiber should be used as a parameter to confirm total vein thrombosis and, conversely, if it is possible to push it back, this should be taken as a parameter indicating incomplete thrombosis. In such cases, the study recommends repositioning the optical fiber in the reverse direction for supplementary endovenous laser application in the same segment, with no real-time echo-Doppler control. These maneuvers may be less safe, because perforation may occur and go undetected, and less effective, because it is not possible to control whether a single reapplication is sufficient, especially in wider segments, Most authors ${ }^{21}$ prefer to perform endovenous laser treatment in outpatient settings rather than in hospitals. Therefore, perivenous tumescent local anesthesia has to be used to ensure three advantages for the patient: pain reduction; perivenous tissue protection against high temperatures, decreasing the risk of burns; and increased surface area contact between the fiber tip and the vein wall. ${ }^{6,10,25}$ The reason participants in this study were given spinal anesthesia in a hospital setting and were admitted for daytime hospitalization using a "day clinic" system was because they were recruited to a study for a doctoral dissertation. ${ }^{30}$ The objective was to perform a comparative bilateral histological evaluation of GSV fragment segments collected after SFJ ligation and divided into two groups that were compared with one another: one comprising fragments assessed before laser application and the other comprising fragments assessed after laser application. This is also the reason why this article only describes patients with bilateral 
GSV incompetence. Undoubtedly, the treatment with endovenous laser proposed in this study has the disadvantages of requiring hospital admission, spinal anesthesia, and SFJ ligation. However, the patients benefited from phlebectomy of all collateral varicose veins and incompetent perforating veins at the same time, which avoids having to attend several ambulatory sessions. ${ }^{31}$ Another benefit from spinal anesthesia is that perivenous tumescent anesthesia precludes clear vein visualization and distorts echographic parameters needed for real-time endovascular laser control. When the present study was conducted, $980 \mathrm{~nm}$ diode laser was the endovascular laser available in the market. Additionally, the reason for accessing the GSV via the perimalleolar region was that since patients underwent spinal anesthesia we could treat the vein as extensively as possible. However, this decision may have led to higher rates of paresthesia, especially hypoesthesia (Table 3), a situation that could be minimized by obtaining access to the middle third of the leg via puncture, as occurs in most ambulatory settings. ${ }^{32}$ In Brazil, the decision to perform a hospital or an ambulatory procedure depends mostly on the patient's profile and the fact that ambulatory procedures are not usually covered by health insurance plans should also be taken into consideration.Other types of endovenous lasers with different active media that produce longer wavelengths have been tested, and some papers have already been published. ${ }^{1,20,26,27}$ Their findings suggest that certain specific chromophores and their respective absorption spectra increase efficiency and efficacy but establish new variables. The results of this study, without complications and with a negligible rate of recanalization and adverse effects at 1 -year control (Tables 3 and 4), suggest that real time echo-guided ablation without perivenous tumescence is a safe and effective procedure that offers standardization for endovenous laser application and better control of those variables that are already known and of other variables that may emerge as a result of inexorable technological advances.

\section{CONCLUSIONS}

In our series, ablation using continuous mode $980 \mathrm{~nm}$ endovenous laser without perivenous tumescence resulted in photocoagulation with effective occlusion of the GSV under real-time echo-Doppler guidance in a sufficiently controlled way, regardless of vessel diameter.

\section{REFERENCES}

1. Proebstle TM, Moehler T, Gul D, Herdemann S. Endovenous treatment of the great saphenous vein using a 1,320 $\mathrm{nm} \mathrm{Nd:YAG}$ laser causes fewer side effects than using a $940 \mathrm{~nm}$ diode laser. Dermatol Surg. 2005;31(12):1678-83. PMid:16336887.

2. Proebstle TM, Lehr HA, Kargl A, et al. Endovenous treatment of the greater saphenous vein with a $940-n m$ diode laser: thrombotic occlusion after endoluminal thermal damage by laser-generated steam bubbles. J Vasc Surg. 2002;35(4):729-36. http://dx.doi. org/10.1067/mva.2002.121132. PMid:11932671.

3. Bush RG. Regarding "Endovenous treatment of the greater saphenous vein with a 940-nm diode laser: thrombolytic occlusion after endoluminal thermal damage by laser-generated steam bubbles". J Vasc Surg. 2003;37(1):242. http://dx.doi.org/10.1067/ mva.2003.33. PMid:12514620.

4. Kim HS, Nwankwo IJ, Hong K, McElgunn PS. Lower energy endovenous laser ablation of the great saphenous vein with 980 $\mathrm{nm}$ diode laser in continuous mode. Cardiovasc Intervent Radiol. 2006;29(1):64-9. http://dx.doi.org/10.1007/s00270-004-0317-9. PMid:16283576.

5. Palmieri B, Lapilli A, Benuzzi G. Endoluminal diode laser vein damage: preclinic study for vein insufficiency. Minerva Cardioangiol. 2003;51(1):95-99. PMid:12652266.

6. Proebstle TM, Sandhofer M, Kargl A, et al. Thermal damage of the inner vein wall during endovenous laser treatment: key role of energy absorption by intravascular blood. Dermatol Surg. 2002;28(7):596-600. PMid:12135514.

7. Perkowski P, Ravi R, Gowda RC, et al. Endovenous laser ablation of the saphenous vein for treatment of venous insufficiency and varicose veins: early results from a large single-center experience. J Endovasc Ther. 2004;11(2):132-8. http://dx.doi.org/10.1583/031126.1. PMid: 15056020 .

8. Campbell B. New treatments for varicose veins. BMJ. 2002;324(7339):68990. http://dx.doi.org/10.1136/bmj.324.7339.689. PMid:11909771.

9. Lefebvre-Vilardebo $M$. The sapheno-femoral area: anatomic study and concepts for the prevention of varicose recurrences. J Mal Vasc. 1991;16(4):355-8. PMid:1791371.

10. Min RJ, Zimmet SE, Isaacs MN, Forrestal MD. Endovenous laser treatment of the incompetent greater saphenous vein. J Vasc Interv Radiol. 2001;12(10):1167-71. http://dx.doi.org/10.1016/ S1051-0443(07)61674-1. PMid:11585882.

11. Navarro L, Min RJ, Bone C. Endovenous laser: a new minimally invasive method of treatment for varicose veins--preliminary observations using an $810 \mathrm{~nm}$ diode laser. Dermatol Surg. 2001;27(2):117-22. PMid:11207682.

12. Goldman MP, Mauricio M, Rao J. Intravascular 1320-nm laser closure of the great saphenous vein: a 6- to 12-month follow-up study. Dermatol Surg. 2004;30(11):1380-5. PMid:15522018.

13. Hingorani AP, Ascher E, Markevich N, et al. Deep venous thrombosis after radiofrequency ablation of greater saphenous vein: a word of caution. J Vasc Surg. 2004;40(3):500-4. http://dx.doi.org/10.1016/j. jvs.2004.04.032. PMid:15337880.

14. Proebstle TM, Krummenauer F, Gul D, Knop J. Nonocclusion and early reopening of the great saphenous vein after endovenous laser treatment is fluence dependent. Dermatol Surg. 2004;30(2 Pt 1):174-8. PMid:14756646.

15. Gloviczki P. Endovenous treatment of varicose veins: credentialing, quality control and education. Endovascular Today. 2004;1(Suppl):28-9. 
16. Maffei FHA. Diagnóstico clínico das doenças venosas periférica. In: Maffei FHA, Lastória S, Yoshida WB, Rollo HA, editors. Doenças vasculares periféricas. Rio de Janeiro: Medsi; 2002. p. 457-69.

17. Corcos L, Dini S, Anna D, et al. The immediate effects of endovenous diode 808-nm laser in the greater saphenous vein: morphologic study and clinical implications. J Vasc Surg. 2005;41(6):101824, discussion 25. http://dx.doi.org/10.1016/j.jvs.2005.03.002. PMid:15944603.

18. Proebstle TM, Moehler T, Herdemann S. Reduced recanalization rates of the great saphenous vein after endovenous laser treatment with increased energy dosing: definition of a threshold for the endovenous fluence equivalent. J Vasc Surg. 2006;44(4):834-9. http://dx.doi.org/10.1016/j.jvs.2006.05.052. PMid:16945499.

19. Boné Salat $C$. Tratamiento endoluminal de las varices con láser de diodo: estudio preliminar. Rev Patol Vasc. 1999;5:35-46.

20. Bush RG, Shamma HN, Hammond K. Histological changes occurring after endoluminal ablation with two diode lasers ( 940 and $1319 \mathrm{~nm}$ ) from acute changes to 4 months. Lasers Surg Med. 2008;40(10):676-9. http://dx.doi.org/10.1002/lsm.20722. PMid:19065553.

21. Hoggan BL, Cameron AL, Maddern GJ. Systematic review of endovenous laser therapy versus surgery for the treatment of saphenous varicose veins. Ann Vasc Surg. 2009;23(2):277-87. http://dx.doi.org/10.1016/j.avsg.2008.11.002. PMid:19128927.

22. Leopardi D, Hoggan BL, Fitridge RA, Woodruff PW, Maddern GJ. Systematic review of treatments for varicose veins. Ann Vasc Surg. 2009;23(2):264-76. http://dx.doi.org/10.1016/j.avsg.2008.10.007. PMid:19059756.

23. Medeiros CAF. Comparação entre o laser endovenoso e a fleboextração total da veia safena interna: resultados em médio prazo. J Vasc Bras. 2006;5(4):277-87. http://dx.doi.org/10.1590/ S1677-54492006000400007.

24. Viarengo LMA, Meirelles GV, Potério Filho J. Tratamento de varizes com laser endovenoso: estudo prospectivo com seguimento de 39 meses.J Vasc Bras. 2006;5(3):184-93. http://dx.doi.org/10.1590/ S1677-54492006000300006.

25. Gérard JL, Desgranges P, Becquemin JP, Desse H, Melliere D. Feasibility of ambulatory endovenous laser for the treatment of greater saphenous varicose veins: one-month outcome in a series of 20 outpatients. J Mal Vasc. 2002;27(4):222-5. PMid:12457128.

26. Almeida J, Mackay E, Javier J, Mauriello J, Raines J. Saphenous laser ablation at $1470 \mathrm{~nm}$ targets the vein wall, not blood. Vasc Endovascular Surg. 2009;43(5):467-72. http://dx.doi. org/10.1177/1538574409335916. PMid:19628516.

27. Doganci S, Demirkilic U. Comparison of $980 \mathrm{~nm}$ laser and baretip fibre with $1470 \mathrm{~nm}$ and radial fibre in the treatment of great saphenous vein varicosities: a prospective randomised clinical trial. Eur J Vasc Endovasc Surg. 2010;40(2):254-9. http://dx.doi. org/10.1016/j.ejvs.2010.04.006. PMid:20547079.

28. Vuylsteke ME, Thomis S, Mahieu P, Mordon S, Fourneau I. Endovenous laser ablation of the great saphenous vein using a bare fibre versus a tulip fibre: a randomized clinical trial. Eur J Vasc
Endovasc Surg. 2012;44(6):587-92. http://dx.doi.org/10.1016/j. ejvs.2012.09.003. PMid:23084274

29. Corcos L, Dini S, Peruzzi G, Pontello D, Dini M, De Anna D. Duplex ultrasound changes in the great saphenous vein after endosaphenous laser occlusion with 808-nm wavelength. J Vasc Surg. 2008;48(5):1262-71. http://dx.doi.org/10.1016/j.jvs.2008.06.004. PMid:18692355.

30. Gaspar RJ, Simões MJ, Plapler H. Effects of the endolaser in the great saphenous vein to treat the chronic venous insufficiency. J Vasc Bras. 2011;10(1):81-2. http://dx.doi.org/10.1590/ S1677-54492011000100016.

31. Carradice D, Mekako AI, Hatfield J, Chetter IC. Randomized clinical trial of concomitant or sequential phlebectomy after endovenous laser therapy for varicose veins. Br J Surg. 2009;96(4):369-75. http:// dx.doi.org/10.1002/bjs.6556. PMid:19283745.

32. Theivacumar NS, Darwood RJ, Dellagrammaticas D, Mavor Al, Gough MJ. The clinical significance of below-knee great saphenous vein reflux following endovenous laser ablation of above-knee great saphenous vein. Phlebology. 2009;24(1):17-20. http://dx.doi. org/10.1258/phleb.2008.008004. PMid:19155336.

$$
\begin{aligned}
& \text { Correpondence } \\
& \text { Ricardo José Gaspar }
\end{aligned}
$$

Author information RJG - MD, PhD, vascular and endovascular surgeon, Head of the Vascular and Endovascular Surgery Service, Hospital São Camilo Pompéia, São Paulo, SP, Brazil. Director, Instituto Vascular Ricardo Gaspar ANC - Vascular surgeon, Sociedade Brasileira de Angiologia e Cirurgia Vascular.

MJS - MD, PhD, Associate Professor at the Department of Histology and Structural Biology, Universidade Federal de São Paulo-Escola Paulista de Medicina (UNIFESP-EPM) HP - MD, PhD Associate Professor at the Department of Surgery, Universidade Federal de São Paulo, Escola Paulista de Medicina

(UNIFESP-EPM).

Author contributions Conception and design: RJG, HP Analysis and interpretation: RJG, MJS Data collection: RJG, ANC Writing the article: RJC Critical revision of the article: HP Final approval of the article*: RJG, ANC, MJS, HP Statistical analysis: RJG, MJS, RJC Overall responsibility: RJC

*All authors should have read and approved of the final version of the article submitted to I Vasc Bras. 